\title{
Cyclic GMP-mediated intercellular communication in mammalian ovarian follicles
}

\author{
Laurinda A Jaffe ${ }^{1 *}$, Jeremy R Egbert ${ }^{1}$, Leia C Shuhaibar ${ }^{1}$, Lai Wen², Martin Thunemann², Robert Feil ${ }^{2}$, \\ Viacheslav Nikolaev ${ }^{3}$, Jerid W Robinson ${ }^{4}$, Lincoln R Potter ${ }^{4}$ \\ From 6th International Conference on cGMP: Generators, Effectors and Therapeutic Implications \\ Erfurt, Germany. 28-30 June 2013
}

\section{Background}

In mammalian ovarian follicles, granulosa cells keep fully grown oocytes arrested in meiotic prophase. A key inhibitory signal is cGMP, which diffuses into the oocyte from the granulosa cells, where it is synthesized by guanylyl cyclase B/ natriuretic peptide receptor 2 (NPR2) in response to the agonist $\mathrm{C}$-type natriuretic peptide $(\mathrm{CNP})$ [1]. Then in response to luteinizing hormone (LH), cGMP in the granulosa cells and oocyte decreases, promoting resumption of meiosis [2]. The primary mechanism by which LH signaling reduces cGMP in the granulosa cells is by reducing the activity of NPR2; this occurs by a rapid modification of the NPR2 protein, followed by a decrease in CNP in the ovary [3].

\section{Methods and results}

Using knock-in mice expressing the cGMP FRET sensor cGi500 [4], we determined that the cGMP decrease begins in the outer layers of granulosa cells where the G-proteincoupled receptors for LH are located [5]. In these cells, the concentration of cGMP decreases to a plateau level with a half time of $\sim 2 \mathrm{~min}$. Because the cells of the follicle are connected by gap junctions [6], cGMP also decreases in the inner layers of the follicle, and finally in the oocyte, where the [cGMP] decreases with a half time of $\sim 10 \mathrm{~min}$ utes. This rapid cGMP decrease throughout the follicle correlates with our previous finding that the guanylyl cyclase activity of NPR2 has decreased by 50\% at 20 minutes after applying $\mathrm{LH}[3]$.

Because NPR2 activity depends on phosphorylation of several juxtamembrane serines and threonines [7], we investigated whether the LH-induced decrease in NPR2 activity might be due to dephosphorylation. The decrease in guanylyl cyclase activity measured at 20 minutes after LH application was inhibited by preincubating the follicles with the phosphatase inhibitor okadaic acid, suggesting that LH signaling decreases NPR2 activity by dephosphorylating the protein. To determine if dephosphorylation occurred, we immunoprecipitated NPR2 from rat follicle membranes, and separated phosphorylated forms of NPR2 using $6 \%$ polyacrylamide gels containing $25 \mu \mathrm{M} \mathrm{Mn}{ }^{2}$ +-Phos-tag-acrylamide, which retards the migration of phosphorylated proteins [8]. Immunoblotting of these gels showed that a 20 minute treatment of the follicles with $\mathrm{LH}$ reduced the amount of the more slowly migrating species of NPR2, which is consistent with dephosphorylation.

\section{Conclusion}

LH signaling rapidly reduces cGMP synthesis in the granulosa cells of the ovarian follicle, by dephosphorylating the NPR2 guanylyl cyclase. The resulting decrease in cGMP propagates through gap junctions to reduce cGMP in the oocyte, where it promotes the resumption of meiosis.

\footnotetext{
Acknowledgments

This work was supported by a grant from the NIH (R01 HD014939) to Laurinda A Jaffe.

Authors' details

'Department of Cell Biology, University of Connecticut Health Center, Farmington CT 06030, USA. ${ }^{2}$ Interfakultäres Institut für Biochemie, University of Tübingen, Tübingen 72076, Germany. ${ }^{3}$ Department of Cardiology and Pneumology, University of Göttingen, Göttingen 37075, Germany.

${ }^{4}$ Department of Biochemistry, Molecular Biology, and Biophysics, University of Minnesota, Minneapolis, MN 55455, USA
}

\footnotetext{
* Correspondence: ljaffe@neuron.uchc.edu

${ }^{1}$ Department of Cell Biology, University of Connecticut Health Center

Farmington CT 06030, USA

Full list of author information is available at the end of the article
} 


\section{References}

1. Zhang M, Su YQ, Sugiura K, Xia G, Eppig JJ: Granulosa cell ligand NPPC and its receptor NPR2 maintain meiotic arrest in mouse oocytes. Science 2010, 330:366-369

2. Norris RP, Ratzan WJ, Freudzon M, Mehlmann LM, Krall J, Movsesian MA, Wang H, Ke H, Nikolaev VO, Jaffe LA: Cyclic GMP from the surrounding somatic cells regulates cyclic AMP and meiosis in the mouse oocyte. Development 2009, 136:1869-1878.

3. Robinson JW, Zhang M, Shuhaibar LC, Norris RP, Geerts A, Wunder F, Eppig JJ, Potter LR, Jaffe LA: Luteinizing hormone reduces the activity of the NPR2 guanylyl cyclase in mouse ovarian follicles, contributing to the cyclic GMP decrease that promotes resumption of meiosis in oocytes. Develop Biol 2012, 366:308-316.

4. Russwurm M, Mullershausen F, Friebe A, Jäger R, Russwurm C, Koesling D: Design of fluorescence resonance energy transfer (FRET)-based cGMP indicators: a systematic approach. Biochem J 2007, 407:69-77.

5. Bortolussi M, Marini G, Dal Lago A: Autoradiographic study of the distribution of $\mathrm{LH}$ (hCG) receptors in the ovary of untreated and gonadotropin-primed immature rats. Cell Tissue Res 1977, 183:329-342.

6. Norris RP, Freudzon M, Mehlmann LM, Cowan AE, Simon AM, Paul DL, Lampe PD, Jaffe LA: Luteinizing hormone causes MAPK-dependent phosphorylation and closure of $\mathrm{C} \times 43$ gap junctions in mouse ovarian follicles: one of two paths to meiotic resumption. Development 2008, 135:3229-3238

7. Potter LR: Regulation and therapeutic targeting of peptide-activated receptor guanylyl cyclases. Pharmacol Ther 2011, 130:71-82.

8. Kinoshita E, Kinoshita E-Kikuta, Koike T: Separation and detection of large phosphoproteins using Phos-tag SDS-PAGE. Nature Protocols 2009, 4:1513-1521.

doi:10.1186/2050-6511-14-S1-P31

Cite this article as: Jaffe et al:: Cyclic GMP-mediated intercellular communication in mammalian ovarian follicles. BMC Pharmacology and Toxicology 2013 14(Suppl 1):P31.

\section{Submit your next manuscript to BioMed Central and take full advantage of:}

- Convenient online submission

- Thorough peer review

- No space constraints or color figure charges

- Immediate publication on acceptance

- Inclusion in PubMed, CAS, Scopus and Google Scholar

- Research which is freely available for redistribution

Submit your manuscript at www.biomedcentral.com/submit
Biomed Central 